\title{
Problems Faced by Hijras (Male to Female Transgenders) in Mumbai with Reference to Their Health and Harassment by the Police
}

\author{
Anitha Chettiar
}

\begin{abstract}
The Male to Female (MTF) Transgenders in India commonly known as the Hijras are one of the hardly researched, abused, scorned, and callously neglected groups in Indian Society. This paper is part of the doctoral research submitted to the University of Mumbai entitled 'The Status of Hijras in Civil Society: A Study of Hijras in Greater Mumbai.' The objectives of this paper are to showcase briefly the socio economic status of hijras and to understand the problems faced by them with specific reference to their health and the harassment hijras face due to the Police. An exploratory cum descriptive research design with a non-random purposive sampling including the snowball technique was adopted, to collect data from sixty-three hijras cross the districts of Mumbai and Thane from the state of Maharashtra, India. The socio economic status was measured using the Kuppuswamy Scale (2005). Among the hijras, more than half of them belonged to the middle class and about forty percent belonged to the upper-lower class. Majority of hijras stated that they faced several health problems and also problems related to harassment, unlawful penalties, sexual abuse, violence and deprivation of human rights. They chiefly named the police including the traffic and railway police, as perpetrators of violence and abuse.
\end{abstract}

Index Terms - Gender, transgender, Hijra, health, police.

\section{INTRODUCTION}

"Sex is what you are born with, gender is what you recognize and sexuality is what you discover." This was a comment made by one of the first hijra respondents of this study [1]. It seemingly came straight from the heart full of her conviction and philosophy making no attempts to quote any authors or dictionary. The significance in her comment was the ease with which she conceptualized the three constructs which theorists and researchers grapple with.

Kimmel [2] quotes sociologists Candace West and Don Zimmerman about their argument that "gender was less a component of identity - fixed, static- that we take with us into our interactions, but rather the product of those interactions." Emphasizing the social construct of gender they argued that "a person's gender is not simply an aspect of what one is, but more fundamentally, it is something that one does, and does recurrently, in interaction with others." Transgenderism is

Manuscript received April 5, 2014; revised June 20, 2014. This work is original and a part of the doctoral research thesis submitted to the University of Mumbai in December 2009. (Received Junior Research Fellowship [JRF] supported from University Grants Commission, New Delhi in 2002-2004).

Anitha Chettiar is with the College of Social Work, Nirmala Niketan, (Affliliated of the University of Mumbai, India) and is also with the Community Health Initiative and Research Action Group (CHIRAG) working for People Living with HIV/AIDS (e-mail: anithachettiar@rediffmail.com). one such phenomena where the 'transgendering' person.

gradually but recurrently perceives and recognizes his/her gender as different from the one assigned at birth, discovers and unfolds ones' sexuality in the midst of perceived as well as publicly expressed rejection and isolation in society at large. The focus of this study is the Male to Female (MTF) Transgenders in India particularly in Mumbai, commonly known as the Hijras.

Operationally defined, a hijra refers to a human person who appears to have characteristics of both the genders that is masculine and feminine. One who is predominantly physically male who may or may not have undergone castration (removal of penis and/or testicles), vaginoplasty, breast implants and has taken upon a feminine identity wearing female attire and claiming to be a part of the hijra community/cult with a hijra identity. In other words, a person who identifies oneself as opposite to the sex/gender assigned at birth and calls oneself a hijra/transgender/woman/kothi.

Hijra identity does not have an exact match in the modern Western taxonomy of gender and sexual orientation. Mohan [3], in an interview with a well known hijra Laxmi Narayan Tripathi quotes as follows, "A hijra ... is someone who is feminine but not a woman, masculine but not a man, a person beyond the boxes of man and woman. The person follows the rules and regulations of the community, has a guru, lives in feminine attire, may or may not be castrated."

According to Sen [4] transgender is the most commonly used term to describe people who "cross socially constructed gender boundaries." Transgender is a blanket term that covers all people whose sense of gender identity does not match their physiological sex. Most trangendered people are aware of their difference at a very early age. Cross-gender behaviour patterns, including cross-dressing, typically appear by age five supporting theories that transgenderism is rooted in developmental conditions, that it has a physiological origin, and that no amount of therapy, drugs, denial, conditioning, rejection, bribery, cajoling, nagging or anything else will make it go away. If it's 'only a phase' then the phase lasts from age five through death. One known cure, which isn't appropriate for everyone, is surgery changing the body to match the mind [5].

Although the "lesbian, gay, bisexual and transgender community" (LGBT) are often referred to as a group, lesbian and gay people have made considerable advances over the last two decades in claiming their rights albeit relatively, while the transgender people and transsexuals, particularly the hijras in this context who differ from societal gender norms - are still without legal protection for their basic civil rights particularly in India. The Constitution of India in 
Article 19 declares non discriminatory practices on the basis of religion, race and gender yet; several instances of stigma and discrimination prevail among the sexual minorities in India including the hijras.

Indian society is deeply stratified along the axes of class, religion, language, education, which intersect with sexuality to create deeper oppressions. Although hijras have a sort of sanctioned and visible place in Hindu society (especially at weddings, births and festivals), in the contemporary context, it is the gender non conformity of the hijra that has a major impact besides lack of a gender recognition certificate, sexual expression, employment, decent housing, subsidized health care services, and as well as the violence they suffer especially when they choose to take up sex work [6], [7].

Thus the objectives of this paper are to showcase briefly the socio economic status of the hijras and to understand the problems faced by them with specific reference to their Health problems and the harassment hijras face due to the Police.

\section{LITERATURE REVIEW}

\section{A. Etymology and Understanding the Hijras}

A Nepali lexicon noted that the word hijra was derived from the Persian hiz. Hiz meant one who is 'effeminate,' 'disdains woman,' 'a catamite.'[8]. According to Muzaffar Alam, a foremost Persianist, hiz was from old Pahlavi Persian, a sister language of Sanskrit, before the eighth century A.D. $\mathrm{Hiz}$ meant ineffective and incompetent. Other Persianists suggest that the origin of hijra was hich, from the word hichgah meaning nowhere. It meant a person who is nowhere, a thing that has no place, no identity or personality of its own [9].

The Urdu and Hindi word "hijra" may alternately be romanised as hijira, hijda, hijada, hijara, hijrah and is pronounced "heejra" or "heejda". An older name for hijras is kinnar, which is used by some hijra groups as a more respectable and formal term. An abusive slang for hijra in Hindi is chhakka [10].

The primary cultural definition of hijras, however is that they begin life as men, albeit incomplete men [8]. The most obvious expression of hijras as women is in their dress. Wearing female attire and their characteristic clapping of hands is an essential and defining characteristic. Hijras also take female names when they join the community and they use female kinship terms for each other such as "sister," "aunty" and "grandmother". Their language, consists of the use of feminine expressions and intonations. Hence, I choose to refer to the hijras using the feminine pronouns like she, her et cetera.

According to UNDP [11] hijra is an umbrella term for all sexual minorities. It states that "hijra cultures are India's answer to support systems for sexual minorities. Long before the West gave birth to gay lib, India's homosexuals, bisexuals, transvestites, transsexuals and kothis found refuge under this umbrella."

Another way of understanding hijras is by understanding how they are different from eunuchs, transvestites, transsexuals, homosexuals, bisexuals, intersexes and hermaphrodites. All these terms appear to mean the same, but in fact they do not. For instance, the Oxford Minidictionary (1988) describes the eunuch as a "castrated man". The Chambers $20^{\text {th }}$ Century Dictionary (1983) describes eunuch as "a castrated man, especially one in charge of a harem, or a high-voiced singer: an ineffectual person." There is no reference in these definitions to a person's desire to wear female attire and to behave like a female.

The word 'eunuch' is derived from the Greek word "Euneukhos" which literally means 'bed chamber attendant'. [12]. It is in this sense that during the later Mughal period they were put in charge of harems. As eunuchs were sexually incapable, due to emasculation (whether voluntarily or under force), they were considered suitable guards for harems [13].

According to Sharma [14] eunuchs are castrated men who do not necessarily wear women's clothing. The practice of castration in the context of Indian Society can be stated to have originated from the tradition of desexualizing the animals. During the Vedic period horses were often castrated. Following that tradition it used to be males rather than females who were castrated. The practice of castration was very popular for a variety of reasons especially outside India. One of the first reasons for castration was the desire to develop a particular physical and mental make-up. It was noted that performance of castration on children prevented the development of secondary sex characteristics. Such men could be later on used as senior slaves to guard harems. Being castrated these men were less attracted to their families and proved more faithful to their owners and masters.

Transgendered people feel a "persistent discomfort and sense of inappropriateness about one's assigned sex (feeling trapped in the wrong body)" as the diagnosis in the American Psychiatric Association's Diagnostic and Statistical Manual (DSM III) puts it. And rather than change their gender, they want to change their biological sex to match their felt gender identity [2].

Winter and Udomsak [15] quote a study conducted in 1997 by C. M. Cole, M. O’Boyle, L. E. Emory, and W. J. Meyer in North America which primarily devoted to identification of psychiatric disorder among transgenders. It included a short form MMPI (Minnesota M Personality Inventory) to a sub group consisting of $93 \mathrm{MtFs}$ and 44 FtMs (pre- and post surgical). FtMs displayed Mf (=masculinity - femininity) scores well within the normal range for females and therefore appeared to retain characteristics consonant with genetic self. However, the MtFs displayed Mf scores that were far typical of genetic females than males and so seemed to have embraced a cross gender personality to a greater degree than had the FtMs, abandoning male traits to a greater extent than FtMs abandon female traits. The same authors also quote a study done in Netherlands in 1988 by Kuiper and Cohen-Kettenis who interviewed 36 FtMs (Female to Male) and $105 \mathrm{MtFs}$ (Male to Female) post-surgical transgenders. They found that the vast majority had a gender identity consistent with their sex reassignment, and that most were confident and happy in their new role [15].

Zhou J.-N., Hofman M. A., Gooren L. J., Swaab D. F. [16] conducted a study which was the was the first to show "a female brain structure in genetically male transsexuals and supports the hypothesis that gender identity develops as a result of an interaction between the developing brain and sex 
hormones." Swaab concluded that the transsexuals were right in their deep-seated belief that they were assigned the wrong gender at birth [17].

\section{B. Hijras in India}

The Male to Female (MtF) Transgenders in India commonly known as Hijras are one of the hardly researched, and callously neglected groups in Indian Society. While they are almost deified in some circles not only in India but also in many other countries of the world though under different names, they are often considered as objects of curiosity, ridicule, exploitation, and abuse.

Khan [18] reported in one of Mumbai's news daily about the case of a hijra Tina (name changed) whose 'hubby' was allegedly abducted by his family because the boy's parents had always been against his relationship with a hijra. They had married in court after dating for one year despite opposition from the boys' parents. Tina who works for a NGO based in Malwani fumes, "I do not understand what their problem is when two consenting adults have married willingly" [1].

The People's Union for Civil Liberties, Karnataka (PUCL-K), [7] published a monograph on the Human Rights Violations against the Transgender Community mapping "the structural violence, the use of force by state and civil society actors and agencies, and of the images of emancipatory struggles" of the transgender community. The report shedslight on the mainstream society's deep rooted fear of sexual and gender non-conformity, which manifests itself in the refusal of basic citizenship rights to these communities [19]. The report also documented the brutal stories of abuse and sexual violence which negates the claim of equal citizenship and protection for all. It has classified the societal violence against hijras and kothi sex workers on the basis of sites where the violence occurs as well as the context of the violence under the following heads: 1 . Harassment by the police in public places, 2. Harassment at home, 3. Police entrapment, 4. Abuse/Harassment at police stations, and 5. Rape in jails.

The narratives indicate that police constantly degrade hijras by asking them sexually implicit questions, touching their breasts, stripping them, and in some cases raping them. With or without the element of physical violence, such actions constitute a violation of the integrity and privacy of the very sexual being of a person.

On the basis of other narratives, the PUCL [7] report also analyses how the institutions of the family, the law, the medical establishment, and the media are extremely intolerant to gender non-conformity and are actually complicit in the pervasive violence and discrimination which hijras are subject to.

A study conducted in Tamil Nadu [20] on the discrimination faced by hijras in sex work, in the Indian health-care system highlighted that the health care professionals do not know anything about them and do not treat them like other patients. They are often addressed in a disrespectful manner and the staff frequently uses male pronouns which they find very offensive. When the transgenders (called as Aravanis in Tamil Nadu) are reluctant to show their ano-rectal areas, they are subjected to abusive language from the examining physician or the assisting para medical staff. They are admitted to the male ward of the Sexually Transmitted Infections irrespective of their castration status or cross-dressing. Many of them are forced to wear male or ambiguous dress when they are in the male ward. They are also mocked and verbally abused by the co-patients in the ward. Some patients and/or their attendants even sexually harass them and usually other patients and ward staff do not defend them in such situations.

\section{Hijra Population}

The census of India does not list hijras separately; they are usually counted as men, but upon request they may be counted as women. It is thus impossible to say with certainty how many hijras there are in India. Large cities like Bombay or Delhi may have 5,000 hijras living in twenty or thirty localities; the national estimate may be as high as 50,000. [21]. However, the category of 'Others' under Gender was included in the questionnaire of the latest Census of India in 2011. The author fails to see the count of the population of persons of Gender marked other than Males and Females in the official website of the Census of India. [22]. Six emails written in April 2014 to different concerned officials have not yet provided any answers to the query.

With regard to the HIV and STI prevalence among transgender populations in India, UNDP (2010) states "No reliable estimates are available for Hijras/TG women." [11]

Thus is can be concluded that hijras are literally the 'uncounted' lot in many ways.

\section{Methodology}

An exploratory cum descriptive research design with a non-probability purposive sampling including the snowball technique was adopted, to collect data from sixty-three hijras having given their oral consent for the interview, in a span of two years from 2006 to 2008. Hijras are strictly secretive about divulging any information concerning themselves, hence the long span and difficulty in data collection. A multi-tool approach for data collection based on the objectives consisted of a Structured Interview Schedule with closed and open ended questions and four Focus Group Discussions (FGD).

\section{REsUlts}

\section{A. Gender}

All the respondents claimed to be members of the hijra cult/community. However, as seen in Fig. 1, about 36.51 per cent among them also wished to identify themselves as females. No one considered oneself as a man and as Fig. 2 points, though 95.24 per cent respondents said that their biological sex at birth was male and correspondingly during childhood they were raised as boys. Fig. 2 also points out only 4.76 per cent ( 3 out of 63 ) claimed that their sex at birth was that of hijra, that is neither male or female and two among them said that in their childhood they were raised as girls and the third one stated to have been raised sometimes as a boy and at other times as a girl. 


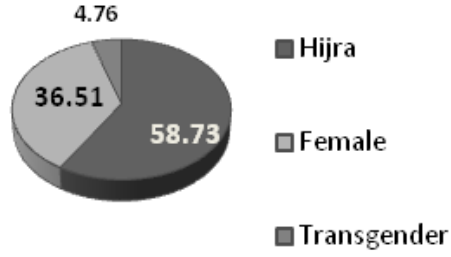

Fig. 1. Present gender.

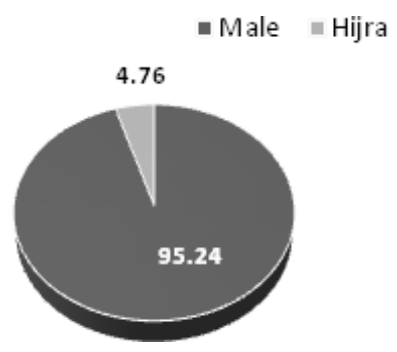

Fig. 2. Sex at birth.

\section{B. Age}

The respondents' age at the time of the interview varied from a minimum of 16 years to a maximum of 70 years in the range of 54. The average age was 31.21 years.

\section{Education}

A glance at Table I reveals that the 'hijra phenomena' cuts across various educational levels. While 19 per cent were illiterate, a huge majority of them were literate and some were also highly educated professionals the highest being a hijra who has completed M.Phil and was pursuing Ph.D. at the time of the interview.

TABLE I: EDUCATION OF HIJRAS

\begin{tabular}{|l|c|c|c|}
\hline \multicolumn{1}{|c|}{ Education } & Frequency & Percent & $\begin{array}{c}\text { Cumulative } \\
\text { Percent }\end{array}$ \\
\hline Illiterate & 12 & 19.0 & 19.0 \\
\hline $\begin{array}{l}\text { Primary School / } \\
\text { Literate }\end{array}$ & 13 & 20.6 & 37.9 \\
\hline Middle School & 3 & 4.8 & 44.4 \\
\hline High School & 15 & 23.8 & 68.3 \\
\hline $\begin{array}{l}\text { Intermediate or } \\
\text { Post } \\
\text { High School } \\
\text { Diploma }\end{array}$ & 9 & 14.3 & 82.5 \\
\hline $\begin{array}{l}\text { Graduate / } \\
\text { Postgraduate }\end{array}$ & 2 & 14.3 & 96.8 \\
\hline $\begin{array}{l}\text { Professional / } \\
\text { Honours }\end{array}$ & 63 & 100 & 100.0 \\
\hline Total & & & \\
\hline
\end{tabular}

\section{Occupation}

Table II shows traditional occupations where 20 out of 63 hijras (31.7 per cent) were employed in projects (NGOs) (though actually not traditional) in Mumbai either run by the hijras themselves or run by the civil society members who have employed hijras in their respective community-based NGOs. These NGOs have a primary focus on HIV/AIDS and related issues. Here it is important to bear in mind that the accessibility and availability of hijras for interviews is possible in such projects, which provided one third of the respondents for this research.
Hijras are one of the target groups for interventions since studies show a high prevalence of HIV/AIDS among hijras.

TABLE II: TRADITIONAL OCCUPATIONS

\begin{tabular}{|l|c|c|c|}
\hline Occupation & Frequency & Percent & $\begin{array}{l}\text { Cumulative } \\
\text { Percent }\end{array}$ \\
\hline Dancing & 5 & 7.9 & 7.9 \\
\hline Sex Work & 13 & 20.6 & 28.6 \\
\hline Begging & 20 & 31.7 & 60.3 \\
\hline $\begin{array}{l}\text { Employed in a } \\
\text { project }\end{array}$ & 20 & 31.7 & 92.1 \\
\hline Business & 3 & 4.8 & 96.8 \\
\hline Giving tuitions & 1 & 1.6 & 98.4 \\
\hline Unemployed & 1 & 1.6 & 100.0 \\
\hline Total & 63 & 100 & \\
\hline
\end{tabular}

It is also important to note in Table II, that the main occupations (or source of income) of the hijras are mentioned, though they may be also engaging in other types of occupation. For example a hijra who is employed in a project is primarily considered as employed in the project while the same hijra may also be engaged in sex work, begging, et cetera.

The clustered bar chart in Fig. 3 shows occupations of the hijras according to the Kuppuswamy SES scale juxtaposing with the average monthly income of the hijras. It also indicates that the professionals and semi-professionals earn lesser than the unskilled and semi-skilled workers.

\section{E. Income}

After removing two outliers, the average income of the hijra respondents was Rs 7209.02 (Standard Deviation = Rupees 4653.66,). The two outliers were removed by selecting cases 'less than Rs.20,000 only'. The two outliers were Rs 30,000 and Rs 2,00,000 respectively as average monthly income. The former earned through sex work and the latter by dancing in bars and occasional sex work with elite personalities including a well known politician.

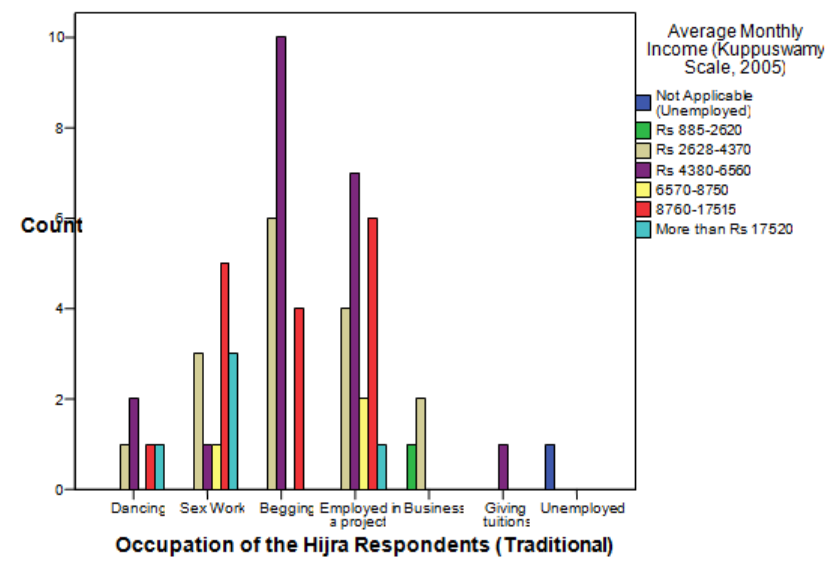

Fig. 3. Occupation and income of hijras.

\section{PROBLEMS FACED BY HIJRAS}

This paper also tried to understand the problems faced by hijras in civil society. It limits it's presentation only to their health problems and the problems faced due to police harassment.

\section{A. Health Problems}

Almost 40per cent $(\mathrm{N}=63)$ said that they do suffer from 
one or the other kind of illnesses. Five of them said they suffered from low/high blood pressure, four of them were diabetics, one of whom also suffered from a bad wound on the leg. She said she takes injection twice a day for controlling her diabetes and a tablet in the afternoon for the wounded leg. She was housebound because of this condition.

Four hijras said that they were HIV positive and were under treatment either Anti Retroviral Therapy [ART] or just on multivitamins from a private doctor since their CD4 count is good enough. Two of them had taken some treatment from Humsafar Organization, another was under the treatment of Medicines Sans Frontier in Khar Danda. One of the HIV+ respondent also complained of pain due to lumps in her breasts probably caused due to regular intake of hormones for breast development for 20-30 years. Among those who suffered from HIV and AIDS, many expressed a need for palliative care especially for terminally ill hijras in a hospice for hijras either run by government or an NGO. This need was also strongly voiced in the focus group discussions. However no one mentioned about such a project to be initiated by the hijra community. An area of great concern is the increasing number of hijras who are HIV positive and do not reveal their status, nor take treatment and thus succumb to the disease at a very young age. The researcher was saddened to know that two of her young and seemingly 'healthy' hijra respondents had expired within a span of six months due to AIDS. Both these respondents had not disclosed their HIV status to the researcher.

Hijra suffering from knee pain also complained of rashes on her tongue but had not revealed her HIV status. She also shared that her knee pain is primarily due to repeated climbing up and down the shops for begging. Hence now she prefers begging on the highways at signals.

Three hijras complained about post surgical complications, either post-castration (which usually many get done in Cuddapah in Andhra Pradesh in a small medical set up. Here a hijra is charged around Rs 5000 for the procedure, and if $\mathrm{HIV}+$ is charged around Rs 8000 for castration. One hijra was recovering from a vaginoplasty done in one of the Municipal hospitals in Mumbai. One of the groups during the focused group discussions expressed the need to follow the example of the Government of Tamil Nadu where free surgical castration was made available to hijras in all Government Medical Hospitals starting from the one at Vellore. Such a facility would prevent hijras from going to quacks and risk further complications.

About ten individual hijras shared that they suffer illnesses like knee pain (mainly caused due to strenuous walking and climbing during begging whether in trains or shops), cold, flu, typhoid, malaria, skin allergy, stomach pain, allergic asthma, acidity, piles, herpes and Sexually Transmitted Infections (STI). Those who suffered herpes and STI infections also did not reveal their HIV status.

Many hijras, both in the individual interviews and in focus group discussion have been appreciative of the treatment and attitude of private doctors in their clinics. The private doctors interviewed were also positive about the hijras who come for treatment and who pay the fees promptly. Some of the extracts from the FGDs are as follows:

Many hijras do not like to go to Government hospitals.
When asked why, they promptly replied, "When ordinary people find so much difficulty in availing of services then what about us ... and even when we do go, the doctors first look at us from top to bottom as though they have never heard nor seen us before and think we are a strange species come from a zoo.... And if we have to be admitted there is a discussion about in which ward we should be admitted however in a few hospitals without any issue they admit us in female wards. The fear of being admitted in the male wards, keeps many hijras away from Government Hospitals." Many hijras voiced similar negative experiences with health professionals in Government hospitals and their need to be admitted in female wards in most of the Focus Group Discussions.

These problems are examined in the context of health problems faced by hijras and the treatment they follow. With regard to the treatment many hijras prefer allopathic doctors in private clinics. In the data from civil society, doctors also have shared their positive experiences of treating the hijras who come to them and who pay their fees without fail. Some of them adopt home remedies for minor illnesses like cold, stomach pain, acidity, flu etc. One hijra who was HIV + shared that she was earlier following Siddha treatment for HIV which was prescribed by the Tambaram Hospital in Chennai. However, she was currently under ART from Medicine Sans Frontier in Khar Danda, Mumbai.

\section{B. Problems Faced due to Police Harassment}

The bar chart in Fig. 3 shows the distribution of the members of civil society who were named by hijras as those responsible for the problems they faced.

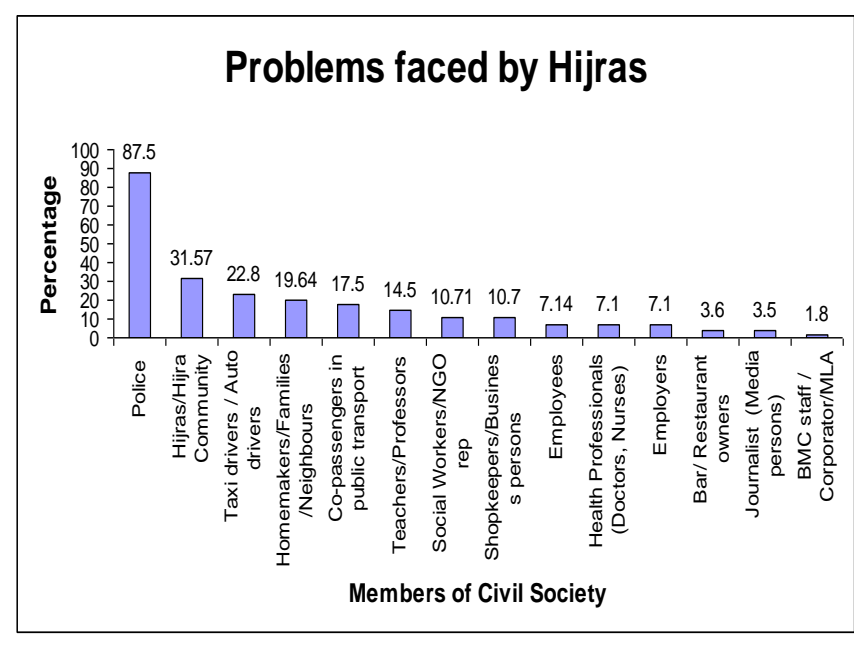

Fig. 3. Problems faced by hijras.

A great majority of the hijras (87.5per cent) stated that they have experienced problems caused by the police whether policemen from respective police stations (50.87per cent), railway police (26.31per cent), or traffic policemen $(8.77$ per cent). Many expressed heart rending experiences which were recorded under open ended questions.

However, before presenting the accounts of police harassment, certain positive experiences needs to be mentioned here. Two hijras commented that "I am good, so all are good. They are my friends., " another proudly said, "I am very decent in my begging. So am not troubled." 
Commenting on a Railway police woman's reaction, one hijra respondent added, "Once a railway policewoman asked me to show my ticket, I told her 'I am a pottai', she replied 'Oh! Sorry' I swayed my way out very gracefully ..." It is important here to take note of the findings from the data of civil society about women being more favorable to hijras than men. This probably could be the reason for the favourable response of the railway police woman.

Of those who were harassed often, two of the hijras said they were beaten up by the police and warned not to beg. Of those troubled because of sex work said, "Often I am not allowed to solicit clients for sex. But many police men have had sex with me.," and another added, "The policemen don't allow me to do sex work , but would demand free sex."

There were also incidents narrated by some which definitely violates their basic human rights and the culprits go off scot free because of the lacunae in the law.

One of the hijra respondents who was travelling with a valid ticket, narrated the atrocity committed by policemen on her. She said, "At Vasai railway station policemen saw me, and told me enter the first class railway compartment. Twelve police men took turns and raped me in the first class compartment between Vasai and Borivali. At Borivali I was pushed out, I somehow dragged my feet towards an autorickshaw and reached home, bleeding profusely ...." This incident echoes Sachin's testimony of police harassment in Bangalore reported by the People's Union for Civil Liberties, Karnatak. (7) Similarly, two more hijra respondents narrated experiences of being gangraped by policemen as punishment for traveling ticketless. Another hijra who was caught ticketless narrated "In 2000, I was caught ticketless at Santacruz Raliway Station, I was publicly stripped and beaten and taken to Bandra police station. This appeared as a headline in one of the leading newspapers. Since I had condoms in my bag for free distribution, they mistook me for a sex worker. The NGO for whom I was working fought for me and subsequently got the police who beat me suspended. I had good media support also at that time. In my case, the media positively took up for my cause".

A hijra caught and kept in a woman's cell narrated, "Once a policeman disguised himself as a customer in the bar and made me the target to raid the hotel and bar. He exposed me as sex worker after having removed my blouse. He even asked if my boobs were real. I said 'yes' though it was a silicon breast implant. Subsequently along with other girls I too was put in the ladies custody for two days. On the day of physical examination the doctors revealed that I was not a woman. Fortunately for me the whole issue took a different turn and the judge questioned the jail personnel how they kept a hijra in a woman's cell (though that's what we MTF transgender desire and demand to be kept with women in judicial custody). For my luck since I was not a 'woman' in their eyes they left me scot free."

It is interesting to note how a hijra had taken a 'sexual contract' with the police in her stride, "One policeman is my fixed client in Sanpada. He gives me Rs 100 per day (2-3 times a week).... However I do not see this as any trouble as such, because this later on helps me to continue my business without any hassle ..."

Besides all the above mentioned experiences, many other hijras have also narrated how some police have warned them not to beg and have let them go scot-free. However, many hijras were not that lucky and hence had to pay a fine several times with or without receipts and in one case the receipt mentioned a lesser amount than what was collected.

\section{IMPLICATIONS FOR SOCIAL WORK PRACTICE}

The profession of social work and its definition have evolved and have opened new horizons in practice over a period of time. The post modern theories and International Instruments also have added new perspectives in practice especially with the marginalized groups in society, to bring out their grievances, experiences and world views.

Promotion of human dignity, human rights, democratic participation of people, peaceful and collaborative social relationships and with regard to the unequal relationships and marginalization of people due to sex, age, ethnicity, caste and creed are some of the goals envisaged by the representatives of the schools of social work in India around 2004 who made efforts "to formulate national standards and develop their mission and goals to address human rights violations that are victimizing marginalized communities through denial of access to resources and services" [23]. This study which explored one of the marginalized groups of society, i.e. that is the hijras, has made some efforts to bring out the experiences of hijras in their own words and understanding.

The study has also provided a closer look at hijras who see themselves as a 'third gender'. This articulation and language is clearly defying the binary constructs of the gender by the patriarchal society as male and female only. The concept of a third gender raises many questions with regard to the stereotyping of gender roles. In a society where the gender roles of male and female are strictly specified, hijras as human beings, find themselves 'trapped' as female soul in a male body. In other words there is a definite clash here between what nature or biology expresses and what society dictates through its rigid social constructs of gender.

\section{A. Right to Self Defined Gender}

The International Bill on Gender Rights [24] in its very first article enlists the civil right to define one's own gender identity regardless of chromosomal sex, genitalia, assigned birth sex, or initial gender role; and further, no individual shall be denied Human or Civil Rights by virtue of a self-defined gender identity which is not in accord with chromosomal sex, genitalia, assigned birth sex, or initial gender role and as a corollary to this, it adds the right to free expression of one's self-defined gender identity. Given these two rights the IBGR also states the Right of Access to Gendered Space and Participation in Gendered Activity. It also elaborates that given the right to define one's own gender identity, individuals should not be subject to psychiatric diagnosis or treatment solely on the basis of their gender identity or role.

It is also encouraging to note in 2004, the Parliament of the United Kingdom passed the Gender Recognition Act (25). In India too it is commendable that certain states like Tamil Nadu in the South, which is seemingly conservative, is making efforts to officially recognize the 'third gender' as 
regular members of the civil society. Such initiatives can definitely provide hijras a civil and political identity and space in the near future. It can restore the human dignity of hijras as respectful members of society and encourage them to contribute productively to nation building.

The Yogyakarta Principles on the Application ofInternational Human Rights Law in relation to Sexual Orientation and Gender Identity addresses a broad range of international human rights standards and their application to issues of sexual orientation and gender identity [26].

An extremely inspiring effort made by the HRC (Human Rights Council) Foundation's Religion and Faith Program is worth mentioning. It has produced and promoted 'Gender Identity and Our Faith Communities: A Congregational Guide for Transgender Advocacy', based on the contributions of transgender people, their families and clergy. Drawing on a wide array of personal experiences, religious and cultural analysis and diverse faith journeys, it empowers people of faith with the knowledge and skills necessary to transform their communities and congregations into welcoming environments. It also aims to turn participants into advocates for transgender rights [27].

The study enumerates a number of stories of violations of their civic and political rights by the police. The rape law which can protect a woman becomes toothless to protect when the same violation is done against hijras. Sexual favours, bribes, corruption etc are criminal situations perpetrated by the authorities of law and order too while they blame hijras as antisocial groups. [4] It is important in this context to emphasize the need of gender sensitization among police force, not just about the rights of women alone, but also of the sexual minorities and transgenders. This is a serious aspect to consider when one talks of civil liberty of citizens.

Hence, an understanding of the complexities of human life needs to evolve in the Indian Judiciary and legislation in recognizing the rights of hijras/transgenders as equal citizens of India.

There is a pressing need to look into the deprivation of civic amenities on the basis of gender and make efforts for the following provisions:

1) Right to get a passport, ration card, voters identity card, pan card, bank accounts, debit and credit card facilities, make a will and inherit property needs to be available to all regardless of change in gender/sex identities.

2) Right to travel legally in ladies compartments in trains, use seats meant for ladies in other public transports and access to use of ladies toilets and bathing rooms.

3) Right to marry a person irrespective of sexual preferences, seek adoption (even as single parent), donor insemination, or surrogacy through accessing official reproductive technology sites as a 'couple' needs to be made available.

4) Right to Divorce and alimony in cases of violence, abuse, fraud etc.

5) All government and non government applications forms for whatever purposes, to have three options for gender, namely Man/Woman/Transgender.

6) Census Data to cover the hijra population and their demographic indicators.
7) Issuance of identity card for hijras to distinguish them from fake hijras.

8) Initiating adequate pension amount for hijras who are above 60 years.

9) Right to Housing: Hijras look forward to free/subsidized housing policies.

10) Initiating coverage of hijras from the lower economic status for employment guarantee schemes and minimum wages Act.

11) Disbursing Interest free loans for hijras skilled in business entrepreneurship with minimum or no formalities.

12) Educational Institutions need to identify students with hijra/transgender orientation and make space for acceptance and discourage any kinds of abuse. Formulate penalties for those causing abuse. Contact the families of students in 'transition' and organize family and community based support systems. Make concessions on cut off points for hijras seeking admission in educational institutions and providing scholarships to hijras who belong to the low socio economic class.

13) Provision of free legal aid. Make recommendation to the law ministry to recognize the rights of the Hijras to marry, adopt and be protected by other laws as just for women.

14) The Indian Medical Council (IMC) and Indian Council for Medical Research (ICMR) need to respond to the issue of transgenderism and transsexualism. Necessary codes and guidelines need to be formulated regarding Sex Reassignment Surgery (SRS) and other procedures that hijras usually seek, namely mammoplasty (breast implants), facial hair removal, scalp hair growth, hormonal supplements and changing of voice.

15) Similarly IMC needs to issue guidelines to ensure that discrimination in medical treatment of hijras, which would include refusal to treat a person on the basis of their gender identity, is treated as professional misconduct.

Further, necessitate reform in medical curricula in medical colleges that moves beyond seeing transgenderism as a disease and a deviance.

\section{CONCLUSION}

All hijras are human beings and logically all human rights apply to all hijras. As all human beings have the right to live with dignity at all times, regardless of their legal, social or political status so do hijras. The content analysis of the problems narrated by the hijras revealed that the majority of them $(87.5 \%)$ suffered harassment at the hands of the police (both railway and traffic) particularly for begging and soliciting clients for sex work. There have also been cases when hijra respondents have been raped and even gang raped by the police especially in the first class compartments of the local trains in Mumbai. Few hijras complained that they suffered inhuman and disrespectful treatment especially in the Government hospitals at the hands of the doctors and nurses.

The emerging global system is redefining the roles of state, 
business, and civil society in the protection and promotion of human rights especially of the marginalized groups. Citizens and civil society are the main and most responsible actors in such processes. No single actor can be expected to provide for the fulfillment of all human rights. But by working together progress is possible [28].

An on-going interface between the hijras and civil society through further research, mutual dialogue and coordinated efforts involving all sectors at the national and international levels could be the key to mainstream hijras into civil society.

\section{ACKNOWLEDGMENT}

Special thanks to all the hijras who participated in the study and especially leaders of the Community Based Organizatons like Sakhi Char Choughi Trust in Malwani, Malad, Mumbai and Astitva in Thane who supported in this research endeavour.

\section{REFERENCES}

[1] A. Chettiar, "The status of hijras in civil society: a study of the hijras in greater Mumbai," Ph.D. Dissertation, College of Social Work Nirmala Niketan, Mumbai, 2009.

[2] M. S. Kimmel, The Gendered Society, New York: Oxford, 2004, pp.106-107.

[3] S. Mohan, "More than a woman no less than a man," (In an Interview with Laxmi Narayan Tripathi in Mumbai), Aids Buzz, New Delhi: Resource Centre for Sexual Health and HIV/AIDS, June 2007, p. 2.

[4] I. Sen, Human Rights of Minority and Women's, (Transgender Human Rights), Delhi: Isha Books, 2005, vol. 2, pp. 4-41.

[5] Diane Wilson. (2001). Gender, Opinions, Support, Resources. Who Are These Transgendered People. [Online]. Available: http://www.firelily.com/gender/resources/who.html

[6] Yogyakarta Principles. (2008). [Online]. Available: http://www. yogyakartaprinciples.org

[7] People's Union for Civil Liberties, Karnataka (PUCL-K), Human Rights Violations against the Transgender Community: a Study of Kothi and Hijra Sex Workers in Bangalore, Bangalore: PUCL-K, 2003.

[8] S. Nanda, Neither Man nor Woman: The Hijras of India, California: Wadsworth Publishing Company, 1990.

[9] Z. Jaffrey, The Invisibles: A Tale of the Eunuchs of India, London: Phoenix. 1996.

[10] Hijra (South Asia). (n.d). (July 13, 2014). In Wikidoc. [Online]. Available: http://www.wikidoc.org/index.php/Hijra_(South_Asia)

[11] United Nations Development Programme (UNDP) India. (2010). Hijras/Transgender Women in India: HIV, Human Rights and Social Exclusion. [Online]. Available: http://www.undp.org/content/ dam/india/docs/hijras_transgender_in_india_hiv_human_rights_and_s ocial_exclusion.pdf

[12] V. Shingala, The Life Style of the Eunuchs, New Delhi: Anmol Publications, 1987.

[13] V. V. Varkey, "Hijras and human rights," Master's Term Paper Mumbai: College of Social Work, Nirmala Niketan, "unpublished," 1999.

[14] K. S. Sharma, Hijras: The Labelled Deviants, Delhi: Gian Publishing House, 1989.

[15] S. Winter and N. Udomsak. (Jan-Mar 2002). Male, Female and Trangender: Stereotypes and Self in Thailand. The International Journal of Transgenderism. [Online]. vol. 6. Available: http://www.symposion.com/ijt/ijtvo06no01_04.htm.

[16] J. N. Zhou, M. A. Hofman, L. J. Gooren, and D. F.Swaab. (1997). A Sex Difference in the Human Brain and its Relation to Transsexuality. International Journal of Transgenderism [Online]. 1(1). Available: http://www.symposion.com/ijt/ijtc0106.htm
[17] N. Aggarwal, "What does the brain have to do with sex?" Times of India, Mumbai, June 1, 1997.

[18] D. Khan, "Transgender says hubby has been abducted by his family," Mumbai Mirror, Mumbai, p. 4, February 25, 2009.

[19] S. Narrain, "Gender Issues in a twilight world," Chennai: The Hindu, Frontline, vol. 20, issue 21, Oct. 11-24, 2003.

[20] V. Chakrapani, T. Ebenezer, S. Fernandes, and M. Jonson, "High-risk sexual practices among hijras in commercial sex work in Chennai, Tamil Nadu: Implications in prevention and control of HIV," in Proc. the International Conference on AIDS, AIDS India 2000, Chennai, 1999.

[21] S. Nanda. (1996). "Hijra." Encyclopedia of World Cultures. [Online] Available: http://www.encyclopedia.com/doc/1G2-3458000491.html

[22] Government of India Census. (2011). [Online]. Available: http://www.censusindia.gov.in/2011census/PCA/PCA_Highlights/pca _highlights_file/India/Chapter-1.pdf

[23] M. Alphonse, P. George, and K. Moffatt, "Redefining social work standards in the context of globalization: lessons from India," International Social Work, vol. 51.no. 2, pp. 145-158. March 2008.

[24] International Bill on Gender Rights (IBGR). (1993). International Conference on Transgender Law and Employment Policy (ICTLEP). [Online]. Available: http://my.execpc.com/ dmmunson/billrights.htm

[25] Gender Recognition Act (GRA). (March 2, 2009). [Online]. Chapter 7. Available: http://www.opsi.gov.uk/acts/acts2004/ukpga_20040007_en_1

[26] M. O'Flaherty and J. Fisher. (2008) Sexual Orientation, Gender Identity and International Human Rights Law: Contextualizing the Yogyakarta Principles. Human Rights Law Review 8:2 Oxford University Press. [Online]. Available: http://www.yogyakartaprinciples.org

[27] Human Rights Council. (2009). [Online]. Available: http://www.hrc.org/issues/transgender/13408.htm

[28] A. Cheria, S. Petcharamesree, and Edwin, "A human rights approach to development: Resource book," Bangalore: Books for Change, 2004, p. 127.

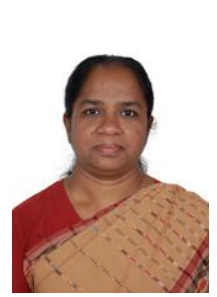

Anitha Chettiar was born on June 13, 1968 in Mumbai She is an assistant professor in the College of Social Work, Nirmala Niketan, Mumbai, since 2004 she has been teaching research methodology and work with groups for both undergraduates and post graduate students. She speaks fluent English, Hindi, Marathi and Tamil. She has completed her matriculation studies in Coimbatore in 1985 with a first class and thereafter received a diploma in education (D.Ed.) from the S. K. Somaiya Junior College of education, Vidya Vihar, Mumbai where she received the 'Best student' award in 1987. She passed with a first class in B.A from the directorate of distance education, University of Mumbai from 1987-1990. As a member of a catholic religious order, she successfully completed her bachelors in theology from Jnana Deep Vidhyapeeth, Pune from 1995-1998.

From 1999 to 2001, Anitha embraced social work as a profession and completed her masters in social work (MSW) from Nirmala Niketan, Mumbai where she received the 'Dorothy baker' award for securing second rank in the final year MSW. She worked as a social worker in Sakhya; a women's guidance cell and currently is also the honorary director of Chirag working on the issues of HIV/AIDS since 2010.

Dr. Chettiar was felicitated by 'V care' on the occasion of woman's day in 2010 for her contribution to transgender studies by way of her Ph.D. from the University of Mumbai, her thesis entitled "The status of hijras in Mumbai and the attitude of civil society towards hijras." submitted in December 2009 She has also participated in various workshops and conferences both nationally and internationally. She has been extensively involved in research related activities and offered consultancy services to various individuals and groups. She was invited to the University of Hesso, Sierre, Switzerland in May 2012 for teaching the undergraduates of social work at their international teaching week program. 